\title{
Starting from anywhere, making connections: Globalizing urban theory
}

\author{
Jennifer Robinson
}

The space for intersection between initiatives to post-colonialize urban studies, and the voices of scholars of cities "after transition" from socialist political and economic orders, is expanding. A series of interventions, including those in this collection, have proposed openings from experiences of socialism and post-socialism to analyses of all cities, including an awareness of the strong cultures of privatism driving forms of micro-gating and hyper-postmodernism in the built environment (Hirt 2013), to the extensive suburbanization with all its environmental implications, consequent upon rapid deregulation of land use management (Stanilov and Sýkora, 2014), opening up conversations about informalization of economy and society (Smith, 2009), mobilizing methodological innovations to deterritorialize post-socialism with close attention to specific continuities and anti-continuities rather than a blanket categorization (Tuvikene, 2016), as well as an awareness that the transitions with their epi-centre in the former Eastern Bloc had massive implications for many other places too, with the demise of the Cold War and, for example, the demilitarization that followed having major impacts on cities like Los Angeles (Tuvikene, this volume). As Golubchikov (this volume) notes, "transition has been a project of planetary significance". Post-socialism "as process not container" is suggestive of many opportunities for conversations with scholars of other contexts, not least with places having undergone political and economic transitions in the same time frame, for example, from authoritarianism to democracy (Brazil, South Africa), or liberalizing economies (such as India) (Harrison and Todes, 2014).

Ferenčuhová (2016) is right to counter this embrace of opportunities for recentering urban studies on the cities marginalized by their incorporation in (post)-socialist orders, with the insistence that the historical and institutional contexts of scholarly work in these places have shaped and limited the range of openings and wider theoretical conversations in urban studies tracking through post-socialist contexts, both historically and today. Although I think she underestimates how significant the housing classes debate, with strong inputs from scholars in and of the socialist bloc, was in Anglo-American urban studies; the similar experiences of "West" and 'East' in public housing delivered a framework for the intense and sometimes ugly transition from Weberian and orthodox social science approaches to a definitive Marxism which still frames core western urban studies research today (Robinson, 2014; Rex; Pahl; Saunders; Harloe). Her concerns are shared by scholars writing in and about cities in Africa, where institutional resources are meagre and policy demands pressing. The call for a more methodologically and stylistically diverse urban studies is intensely presented by Parnell and Pieterse (2016) who insist that an urban theory without Africa is an impossibility, and propose more transversal practices, embedded in practical terrains of often politicized forms of knowledge 
production. Moreover, in a moment of shifting centres of urban studies, African and post-socialist contexts face the possibility of being doubly marginalized, as Asian urbanization and the growth of mega-urban regions overshadows interest in these contexts. How might these concerns and commitments, from very different regions, support and inform one another?

In this emerging intersection, then, I am delighted to offer some thoughts stimulated by this excellent collection of papers, and the event they emerged from, the $6^{\text {th }}$ international Conference on Cities After Transition, '25 Years of Urban Change' September 2015. My comments here emerge out of the absolute delight I felt in finding a community of scholars, theoretically inspiring and empirically committed to their region - exactly the experiences I associate with the South African urban and geographical community which is my intellectual touchstone. Our connection may be one of pure fantasy (mine), but in my view it also indicates the potential for the idea of building "South-South", or perhaps region to region, collaboration and comparison (Parnell and Oldfield, 2014). I therefore begin here where I ended my talk for this event - with an uncanny fictional tale of connection between postsocialist urban experiences and the South African early post-apartheid moment. It is a tale which rehearses for me the imaginative leaps and bounds across different urban contexts that are needed for urban studies to dislocate itself in order to be relevant for this era of global urbanization. But it also offers a cautionary tale of the misrecognitions possible across diverse and divergent urban experiences, and the fragile recognitions which new trajectories of interpretation can bring into view.

\section{(Urban theory and) Propaganda by Monuments}

The writer of the short story which came strongly to mind when I was preparing to talk at the 2015 Catference, Ivan Vladislavič, is a South African novelist whose somewhat magical realist novels build from the intense juxtapositions and absurdities of urban spaces, a minoritized English language, and the sometimes disturbing overlapping of past, present and future in the intensely hopeful early post-apartheid moment when a number of his significant works were written (Judin and Vladislavič, 1998; Robinson, 2010; Warnes, 2000). In the story I discuss here, he provides an imaginative connection from South Africa to a distant place, Moscow, not hugely present in the imaginations of most South Africans, but part of the network of often socialist places which had supported the anti-apartheid movements in the dark years of exile and in their efforts to build some military capability to take on the apartheid regime. Practically, then, many South Africans in exile lived and studied in various other African and socialist countries. These experiences had a strong impact on South Africa's transition, marking for some senior politicians grounds for a deeper commitment to a liberal, market order, but also bringing into the heart of the new government the intrigues and complexities of the exiled party (Gumede, 2005; Johnson, 2010). Moreover, in the growth of the communist party and the strong union movement, the iconic significance of the Soviet Union is important, and 
ideas from socialist political repertoires like democratic centralism, were very alive in everyday political practice and discussion. We have also seen from Lukas Stanek's (2012) fascinating work on socialist architects and planners in Africa that the lines of connection between cities in these two regions were significant, making a marked imprint on urban form across Africa, and shaping the experiences of those returning to shape and build socialist cities.

Vladislavič brings these rather buried resonances of proximity across seemingly very far apart places to enrich his alertness to the ways in which, especially in times of transition, past, present and future, intertwine in emergent, unpredictable, and sometimes funny urban spaces (Warnes, 2000; Robinson, 2010). Space is for him malleable, as it transforms, activating both the spatial proximities we find in this story and the spatiotemporal dislocations which shape his better known post-apartheid narrative, The Restless Supermarket (2001). In an earlier short story, Journal of a Wall (1989). he uses the vertiginous feeling after drinking too much to set the walls of his house into motion, as bricks peel off, the ceiling drifts away and the walls unravel he is left "floating on the raft of the floor" (p. 256). His sensitivity to "space" as mobile, dynamic, unfixed, reflecting and disturbing our subjective orientation and social co-ordinates, runs through several of his fictional works, and his broader reflections (Judin and Vladislavič, 1998; Vladislavič; 2000; Vladislavič, 2006). In the story we consider here, the distance between places is collapsed topologically through letters, imagination and shared histories (Allen, 2016).

In the short story, "Propaganda by Monuments" Vladislavič puts to work the intense affective and practical links between some of South Africa's political movements and the history and iconography of the Soviet Union and their admiration of the wider achievements of state socialism. The action of the story takes place in the thoughts of two characters, Pavel Grekov, a not very important official in Moscow - "a junior translator in the Administration for Everyday Services, an English specialist" (p. 12); and Boniface Khumalo, a "taverner and taxi owner", running informal businesses in the apartheid-era township of Atteridgeville, on the outskirts of Pretoria, South Africa's capital city, now engulfed in the sprawling city-region of the wider province of Gauteng. Between the two characters, slight physical evidence travels with their letters - a fingerprint in ink from the typewriter ribbon from the translator; a "tight spring of black hair" belonging to Khumalo, which Grekov failed to recognise as "(h)e blew it into space in a cloud of steam" (p. 22) on the cold Moscow street.

Inspired by a satirical leader in the local newspaper, suggesting South Africa's large number of communist party members might make it a good market for Russia's surplus statues (p. 34), Khumalo writes to Moscow saying he is looking for a spare statue of V.I.Lenin, imagining himself as offering a "trade opportunity" between the two countries, following a recent visit from Russian officials to South Africa to encourage trade. In the middle of the story, an "extract" from a putative history text, outlines the origins of 
an actual "monumental propaganda" initiative by Lenin in the 1930s, initiating a Soviet school of sculpture with all the work that ensued. The tale is told in the characteristic minoritized and idiomatic English Vladislavic loves to work with (Helgesson, 2004), and the rather strange translations of the Russian administrator are certainly detaining: "who knows how long ago hence we may eat beefsteaks and drink vodkas - our patriotic highball - in V.I. Lenin Bar \& Grill of Atteridgeville!" (p. 30). The piece of news in Grekov's letter which causes Khumalo some concern, though, is the size of the statue. In order to place the informal and modest nature of the township where he lives in perspective of the modernist "colossal" sculpture, Khumalo heads downtown in Pretoria to visit a statue which is size-wise and stylistically closely related to the Soviet era one he desires - a colossal bust and memorial of the one-time South African president, J.G. Strijdom. Here, then, another line of connection from "us" to "you" - the architectural brutalism and monumentalism of many apartheid-era national buildings.

Khumalo's knowledge of Strijdom, he thinks to himself, is limited to a resistance song, "Sutha, sutha wena Strijdom!' the song said. 'Give way Strijdom! If you don't, this car, this car which has no wheels, will ride over you!" (p. 36). As he approached the head, "his heart sank"... the head he saw was enormous, and the one he had been promised from Moscow three times that size! It would hardly fit in his yard! Perhaps he could knock down his outside toilet and small room, he thinks.

In his visit to the statue, Khumalo is also fascinated by how the statue was able to stay up - and Vladislavic rehearses the debates and fascination there had been with the design of the statue which seemed to be likely to topple over at any moment - "after a while he began to see how, but not necessarily why, the impossible came to pass" (p. 38). Khumalo evokes the precariousness of authoritarian rule as he recalls his own longstanding fantasy that in fact Strijdom was not the serene authoritative figure of the statue, placed so that spectators might stand below his gaze and "metaphorically come under his influence" (Hook, 2005, p. 692), just as Grekov experienced the Lenin statue to be "looking straight at him" (p. 17). Rather, Khumalo had long imagined him as "a slow-footed pedestrian, a moment away from impact and extinction, gaping at the juggernaut of history bearing down on him" (p. 36). The ambiguity of the statue - how can it stay up; what does it stand for - recalls the toppling of statues from the Soviet era. In turn, Grekov ponders the Moscow street he is sitting in without the enormous Lenin statue he had just watched being removed - a single thread of iron "marked the spot where the head had stood. The head of Lenin. It's hard to imagine something else in its place. But that's one certainty we have, he thought. There will be something in its place." (p. 21). The uncanny connection between these two distant places is perhaps completed by history itself, as some 5 years after the story I recount here was published, the statue of Strijdom mysteriously collapsed, on the $40^{\text {th }}$ anniversary of South Africa having declared itself a "Republic" (Hook, 2005). 
Read from now, this moment in which the monumental embodiment of the two recently overthrown regimes, Soviet and Apartheid, seemed to find uncanny resonances and to excavate long-buried, slight, connections is pregnant with uncertainty but also with a hopefulness. In both these contexts today we can say this hope has been betrayed to a greater or lesser extent. The toppled statues, and the divergent, personal meanings and gazes which the bemused Grekov and the protesting Khumalo brought to these symbols of power signify nothing less than the numerous potential afterlives (Benjamin) of these urban artefacts, consigned to the "scrap heap of history" as workers narrated the fate of the Lenin head to Grekov, or celebrated by famous union leaders and local shebeen-goers in the backyard of Boniface Khumalo. The filaments of material and imaginative connections between these two places insist that these afterlives belong to each other in some way.

The idea of the multiplicity of "afterlives" subtends some of Walter Benjamin's early propositions about interpreting novels and art without insisting on any original or true meaning of cultural phenomena (Caygill, 1998); in the Arcades Project he extends this to shape his accounts of the reworking of the meaning of urban forms and experiences, including famously as "ruin", as well as more generally to inform the multiplicity of languages, and the multiplicity of possible analyses of history (Benjamin, 1999: 3-7; Robinson, 2013, p. 665-6). Thus, rather than seeing history as temporal, continuous, progression, he proposes to think of the relation between the past and now as a dialectical image, suddenly emergent. A multiplicity of possible analytical constellations mobilise understandings of elements of pasts to produce an interpretation of "now", leaping across time to offer an understanding of specific historical events. We could imagine, then, an "urban now", in which our theorization of the contemporary urban needs to emerge across a multiplicity of precariously or profoundly interconnected urban outcomes, each with distinct trajectories (see also Caygill, 1998; 119). Could we benefit from a similar analytical architecture, to think across how both pasts and elsewheres shape the numerous, if not infinite, possibilities of the urban? In my view, in this globalising and interconnected urban world we have little choice but to develop a theoretical practice which straddles a multiplicity of (already interconnected) urban contexts, alert always to difference, while seeking to benefit from shared insights on urbanization in our engagements with different contexts (Robinson, 2016).

This, then, brings me to what drew me to return to this story of Grekov and Khumalo - the analytical potential of thinking with the, sometimes slight, but very real shared processes stretching like so many shimmering gossamer threads across significantly divergent urban contexts. In pursuing these threads - like the slender iron thread, or the invisible mechanisms holding up the two statues in the tale - mistranslations and miscomprehensions, misrecognitions certainly abound, but so do the tenuous yet immensely powerful insights which thinking with these connections might generate. These resonances - traces of empirical 
historical connections, parallel processes or uncanny resemblances, even emergent fantasies stretching across time and space to make a distant place proximate - each in their way index the possibility of thinking differently, of starting somewhere, arced through the unfamiliar, to instigate incipient thoughts and stumbling vocabularies, formed as much with the achingly familiar as with the impressively strange in mind.

This, for me, is the imagination of comparison - thinking with elsewhere, disturbing taken for granted insights, taking the gift and the pleasure of the initially perhaps gossamer thin conceptual association or empirical connection to build a new story, an analysis which might in time become rich with the joys of new words and disturbed conventions. ${ }^{1}$ I have tried to talk about this through a range of different theoretical languages (Robinson, 2016) - from a Marxist concern (following Lefebvre, 2009) with the inexhaustible fullness of empirical worlds; to being inspired by the "now" of Walter Benjamin in which we might draw together insights on the nature of the urban from across the spaces and times of the world of cities; to the sense of concepts emergent in our practical encounters with the world, presented to us in Deleuzian fashion, as a "problem" to which we also bring the resources of concepts drawn from elsewhere; to the possibility of experimenting with the wider purchase of hard-won terms which slowly accrete meaning as scholars grapple with the "difference-without-concepts" they encounter in their close empirical work, perhaps in ethnographic practices, to insist on the potential to name the specificity that inheres in the cities they have encountered.

More broadly, I am eager to see how reformulating comparative methods can give us more strategies through which to think with elsewhere, to decentre theoretical knowledge, and to energise an urban studies whose object has already been significantly recentred beyond the "west". For this reason, amongst others, I have taken enormous pleasure in reading the texts presented in this collection. They deserve to be read by every urbanist I can think of - as they represent a thoughtfulness and creativity in working across different situated literatures and urban experiences, to insist on the wider value of the hard won and incredibly useful analysis that results.

It is the attentive reading of, with and across difference that is the impressive skill of the regional and area studies traditions which are partly what make the post-socialist studies scholars writing here legible to me with my southern African studies background. This key comparative practice careful, reasoned, concerned with detail as much as with the broader concepts - is the fabulous resource of ex-centric scholars of cities across the world, and which the cultures and practices of dominant authoritative knowledge far too frequently completely lack. It is in this sense, then, that Tariq Jazeel (2014) asks us to read planetarity with a Spivakian eye turned to an ever-present alterity; and that the complexity and opacity of urban life,

\footnotetext{
'I enjoyed Rogers' (2010) whose thinking through connections and comparisons, referenced by quite a few authors in this collection, resonated with my own work on comparison.
} 
for Simone (2011), indicates the impossibility of settling the meaning of the urban. The urban, then, is always in question, always open to revision from insights generated elsewhere, or in addition. The papers presented here demonstrate most definitively the potential for new, extended, substantial and articulate innovations in theorizing the urban, to emerge from a range of loosely comparative practices, committed to thinking with elsewhere.

\section{Ways to think with elsewhere}

Reading Practices: Each of the papers in this collection contributes to the regional scholarship of countries which share a period of socialist rule, as well as in each case to the distinctive histories and current experiences of individual cities. In my view these contributions are each in their own right fascinating, whether or not they turn to tasks of comparison, or importing/exporting conceptual insights. These not only form part of the local and national resources for thinking and engaging with the urban in specific places, essential where change is rapid, futures uncertain, and the stakes of politics often quite high; but they are also a rich resource for all urbanists. However, for this to be realised, there is a need for a dissemination of reading practices from relatively ex-centric scholarly communities to those who occupy a position of centrality in so-called international circuits of urban scholarship. One of the richest scholarly resources of many regional studies networks is the skill of reading across different contexts to glean insights, suggestive ways of thinking, which might be relevant in other regions. These skills are in very short supply in more "centric" scholarly communities. The capacity to read closely a very different case, to generate creative and imaginative resources to think with in one's own research - these skills are central to the transformation in reading practices which is essential for a more global approach to thinking the urban. Post-socialist scholars can insist on their work being read differently, and provoke opportunities for northern and western scholars to learn these skills. Rather than simply conforming, then, to the imposing demands of institutionalized academic management (that Borén and Young, this volume, highlight), by "importing" theory and speaking in the language of dominant international norms, there is an opportunity to contribute to developing a genre of urban analysis which brings the best of regional studies practices to a wider urban studies, instigating the transformation of dominant cultures of reading and theorization, through practices which are open to thinking through difference.

Thinking with multiple processes: Bouzarovski, Sýkora and Matoušek investigate a disturbing outcome of arrangements for district heating in one Czech city, Liberec, where prices have skyrocketed. Their detailed investigation brings out the diversity of processes at work to realise this outcome - the persistence of collective heating in some other situations has sustained a socialist element to urban services (Collier, 2013) despite the application of forms of calculation which have neoliberal elements, but in concert with the ways in which privatization of apartments and utilities occurred in Liberec, and also in relation to emergent forms of rule and 
appropriation there, the outcome has been ruinously high prices for the poorest families trapped in centrally located, unrenovated apartments.

There is no doubt this study is extremely important for local scholars and policy makers - but it brings with it insights at a more abstract level. It develops the broader thematic from within post-socialist studies which insists on the multiplicity of processes shaping such contexts, such as modernity, as Hirt (this volume observes), bringing cities like Liberec into close analytical alignment with many other situations struggling with infrastructure provision, for example. It also offers important insights for any scholar anywhere with a case study of privatization, neoliberalization, or decentralization to consider, or who must grapple with local outcomes which are enmeshed with both wider influences and localized trajectories. "Path dependency", these authors argue, requires attention to multiple temporalities and periodicities, including the ways in which quite recent transformations have strong determining effects. The path-creating elements of "socialist legacies, national economic reforms, and local neoliberal practices" need to be considered together and over time, leading them to coin the very useful idea of a "rolling path dependency". And secondly, analysts of neoliberalization find here an essential case to reinforce awareness that outcomes shaped in some way by neoliberalization may not be determined by this, or indeed, even result in an outcome that could be described as "neoliberal” (Robinson and Parnell, 2011).

Finally, Chelcea and Druță (this volume) stretch this analysis further, insisting on the dynamic relationship between discourses of the past and the increasingly non-democratic imposition of "post-socialist" forms of rule. They chart the invention of 'neoliberalism on steroids', as intensified forms of discounting democratic and social justice agendas emerge, potentially recirculating "back" to inform practices in other contexts. Zombie socialism, then, demands a reconsideration of the overly materialist analyses of neoliberalization which shape dominant urban studies approaches (Peck, Brenner, Theodore, 2009) and brings forward the power of ideological and political discourses to transform urban outcomes.

Thus at the widest scale, how we approach cases, whether or not they directly speak to one another empirically, frames a vast agenda of shared conceptual issues, either at the level of quite abstract or widespread processes, or at the level of some fundamental conceptualizations of history, such as path-dependency. Dispensing with post-socialism as container or overarching descriptor of cities in Central and Eastern Europe, as Hirt (this volume) rehearses, opens cities in this region to such shared conversations.

Revising concepts: Bernt makes a much more determined engagement between two cases of residential change, in Berlin and St Petersburg, and a circulating concept, "gentrification" as he explicitly sets out to test and transform this concept through reflection across his cases. The distinctive processes of property rights transformation and regulation (of rents, heritage controls) in the two cities framed the nature of urban change. A splintered 
gentrification emerged in St Petersburg where rich and poor shared neighbourhoods with continuing involvement of the state in managing only partly-privatized blocks; in Prenzlauer Berg, in Berlin, restitution of property and tax subsidies led to large scale sales and speculation, with ensuing increase in both rents and property values, and a change in residents - does this add up to gentrification? Bernt suggests that the borrowed concept of gentrification hides the specific dynamics at work in shaping urban change in these contexts - looking at them differently may open up new and interesting lines of comparison with other contexts (focussing perhaps on issues like rent regulation, privatization, heritage, developer negotiations). As he recommends to both "see and un-see gentrification", he offers a strong critique of the idea of the "rent gap" based on his studies, which bring to the fore the social construction of markets necessitating much stronger attention to the regulatory processes shaping the possibility for urban change. Refining the concept of gentrification through "autochthonous experiences" and also refusing its universalizing ambitions could open up new and confident lines of interpretation.

Again, the cases discussed here are of the widest relevance - although postsocialist transformation has intensified urban residential change over the last decades, the dynamism of all cities means changes, sometimes large scale and epochal, are widespread, whether instigated by policy innovation, by shifting local land markets, political appropriation or transnational extraction of value. Bernt presses this agenda very directly and proposes a recalibration of the term, gentrification. I wonder if, rather than once again tweaking an aging and parochial concept like gentrification, there are other conceptualizations emerging from his cases which might easily capture interest of scholars working in some other places? Liberating a greater diversity of concepts could ensure that processes marginalized by inherited concepts can expand and assume a stronger explanatory role. In the first case, then, of Liberec's heating system, perhaps the interesting and useful travelling concept might be found not in the core (western) theoretical preoccupations of neoliberalism or path dependency, but in the much more pressing and vastly undertheorized phenomenon of how diverse forms of rule shape urban outcomes (e.g. Kinossian, 2011), and help with highlighting and explaining the apparent state of exception at the heart of even the most bureaucratized forms of urban governance (Swyngedouw, 2005).

Conceptualizing Difference: Ouředníček confronts a puzzle which demands such a new, emergent theorization: the meaning of the urban peripheries of many socialist cities, in this case Prague. The morphology of dense socialistera-housing might suggest to Western-influenced observers and theorists an alignment with social outcomes of segregation and class division, while in fact multi-class and valued residential environments are more characteristic. His argument is also ambitious, framed in such a way as to insert these peripheral urban developments into wider conversations at large in urban studies about the importance of peripheries in defining the nature of contemporary urban development in many parts of the world 
(Hsing, 2010; Keil, 2013; Brenner and Schmid, 2015; Caldeira, 2016). This is an important reminder of the complexity of urban cases - thinking across the huge divergence in social meaning of often common urban forms. As we set out to value learning from elsewhere in our encounters with specific cities, this task is far from straightforward. This paper very helpfully rehearses the limits of any kind of developmentalism (socialist cities becoming like "western" ones), or easy application of wider theoretical concepts derived from analyses of social housing, privatization or segregation in other cities. Drawing on a range of different literatures, Ouředníček insists that inductive theorization and empirical research could both enrich international knowledge and develop new concepts for postsocialist research itself.

Theory, then, and wider conceptualizations of "the urban" in the context of a global urban studies, is necessarily hard work. It is slow, requiring a lot of commitment to attending to the complexities of contexts, divergent theoretical idioms and languages, and patiently building from puzzles and incoherencies towards newly framed insights. Theory-building is tough, necessarily incomplete and commonly modest in its engagement across diversity. In contrast, we might want to be wary of theory-broadcasting, seeking to maximise take-up rather than insight, to adopt often pre-given universal postures rather than valuing emerging capacities to think productively across more than one situation.

Extending Theory: What, then, to do with the inspiring, insightful and widely circulated and admired works which we inherit - as Europeans, as those who inhabit certain language domains, or as those who are eager and curious to learn from and appropriate knowledge from anywhere. My own personal view is that we have every right to love and appropriate the rich inheritances of generations of scholars trained in ways we can only dream of today, in our multiple neoliberalizing academies, and technically driven education systems. I was surprised, re-reading Spivak's hugely influential "Can the Subaltern Speak" article (1988), to realise that it was basically a defence of one white European male scholar (Derrida) over another (Deleuze). Drawing on these resources, her work has inspired a generation of post-colonial scholars to frame their own critiques and insights into countless places and processes, in ways which insist on the potential of different experiences to radically recast knowledge. In this light, the impressive paper by Golubchikov brings the broadest theoretical analyses of capitalism and urbanization together with insights on transition, to engage directly in conceptual debates relevant to all theorists of the urban. Rather than back away from "transition" as a lens through which to see countries known as post-socialist, he expands the concept to view it as marking a totality - encompassing the entirety of social orders while reframing their histories - and as planetary, shaping the global order, and not simply postsocialist states.

In this bold manoeuvre he confirms our shared sensibility that from specific concepts to the most ambitious of theories, not only do we have the right to 
appropriate theorizations of the urban from anywhere, but we can also expect that the cities we engage with over long years and decades contribute to the development of new theoretical insights potentially relevant to all cities. In this sense urban theory is being made by communities of scholars in many different parts of the world, whose rights of access to the richest resources of thinking about social and historical change are inalienable; those in well-resourced positions of centrality who do not exercise their rights to learn from the rich labours of regional studies urban scholars anywhere, are on a path in which they risk placing themselves in positions of declining relevance, and certain marginalization.

\section{Concluding thoughts: Changing Theory, Changing Practice}

Sjöberg (2014), in a paper based on his talk to a previous CATference, is disappointed that post-colonialism does not come along with some strong empirical revisionist claims - or new theories. He correctly signposts the attention to ambivalence and complicity in thinking power relations which the post- neatly signified in its engagement with post-colonial historiography and psyschoanalytic treatments. But if the post-colonial is, following Chakrabarty (2001), a method for transforming inherited theory - this is a great potential for urban studies now. Sjöberg calls for fellow scholars of post-socialist contexts to "report back" to urban theory more, rather than remain in the comfort zone of the post-socialist community of scholarship (p. 313). This is of course an important practice if wider conversations about the nature of the urban are to be sustained. But I also think we need a more thorough-going revision of how we perceive and perform "theory". And to demand that those who perform theory from a site of centrality and privilege need to undertake this work in very different, much more modest and collaborative ways. What would these be? Attention at a minimum to what locales and cities influence their insights and practices; openness to a multivocality of theory, and to new subjects of theory (Roy, 2009) - in positionality, age, gender, location there is a veritable bell hooks-ian array of intersectionality and marginality demands attention and a hearing. We would also need to see a practical commitment to institutional activism to open spaces for scholars whose voices are marginalized through resourcepoor contexts and workplaces; and a revisionist approach to publishing norms and expectations to ensure new subjects of theory and theoretical claims can circulate in the exorbitantly privileged circuits of global monopoly publishing.

Here I would like to make an invitation to post-socialist scholars - how about forging links and practically supportive institutional associations with colleagues in very different parts of the world, whose struggles with language and access to books and electronic resources and academic events can make CEE and ex-Soviet institutions seem very well resourced indeed? There are whole worlds of work to be done on the immediate pressing concerns in your own contexts which intrigue, and demand attention from, your scholarly community; but there are other contexts too, which may not 
seem to hold great promise for professional recognition as leading international scholars, but which might both pragmatically and intellectually repay collaborations and engagements. Tuvikene (this volume) indicates the potential for exploring the concept of informality, for example, which would track post-socialist cities to insights generated in cities in India and Africa. Such new engagements could become important sites for a new generation of ex-centric global urban practices and concepts. Especially if we look for creative ways to invent and fund new kinds of collaborations, partnerships, consortiums and circuits of interaction which don't follow the tracks of the powerful networks centred on the "north" "west" but instantiate new geographies of theorizing - "south-east" (Yiftachel, 2011), "south-south" (Parnell and Oldfield, 2014) and "south to north" (Myers, 2014). Come to the next South African cities conference!

\section{References}

Allen, John. 2016. Topologies of Power: Beyond territory and networks. London: Routledge.

Benjamin Walter. 1999. The Arcades Project, MA: Harvard University Press.

Benjamin Walter. 2003. Selected Writings. Vol 4. Cambridge: MA: Harvard University Press.

Brenner, Neil. and Schmid, Christian. 2015. Towards a new epistemology of the urban? City, 19, 2-3: 151-182.

Caldeira, Teresa. 2016. Peripheral urbanization: Autoconstruction, transversal logics, and politics in cities of the global south. Society and Space, online early, doi: 10.1177/0263775816658479

Caygill Howard. 1998. Walter Benjamin: The Colour of Experience. London: Routledge.

Chakrabarty, Dipesh. 2000. Provincialising Europe, London: Routledge

Collier, Stephen. 2005 "Budgets and biopolitics", in A. Ong and S.J. Collier (eds) Global Assemblages: Technology, Politics, and Ethics as Anthropological Problems. Oxford: Blackwell, pp. 373-390

Ferenčuhová, Slavomíra. 2016. "Accounts from behind the Curtain: History and Geography in the Critical Analysis of Urban Theory." International Journal of Urban and Regional Research 40: 113-131. 
Gumede, William. 2005. Thabo Mbeki and the Battle for the Soul of the ANC. Cape Town: Zebra Press.

Harrison, Philip, and Alison Todes. 2015. Spatial Transformations in a "Loosening State": South Africa in a Comparative Perspective. Geoforum 61: 148-162.

Helgesson, S. 2004. 'Minor Disorders': Ivan Vladislavic and the Devolution of South African English. Journal of Southern African Studies, 30, 4: 777787.

Hirt, Sonia. 2012. Iron Curtains: Gates, Suburbs and Privatization of Space in the Post-socialist City. Malden, Oxford, Chichester: John Wiley and Sons.

Hook, Derek. 2005. Monumental Space and the Uncanny. Geoforum, 36,6: 688-704.

Hsing, Yi-Tien. 2010. The great urban transformation: the politics of land and property in China. Oxford: Oxford University Press.

Jazeel, Tariq. 2014. Subaltern geographies: Geographical knowledge and postcolonial strategy. Singapore Journal of Tropical Geography, 35: 88103.

Johnson, Robert. W. 2010. South Africa's Brave New World: The Beloved Country since the End of Apartheid. New York: Overlook Press.

Judin, Hilton. and Ivan Vladislavić. (eds.) 1998. blank : Architecture, apartheid and after. Rotterdam: Netherlands Architecture Institute.

Keil, Roger. (ed.) 2013. Suburban constellations: governance, land and infrastructure in the 21st century. Jovis Verlag, Berlin.

Kinossian, Nadir. 2012. 'Urban entrepreneurialism' in the Post-socialist City: Government-led Urban Development Projects in Kazan, Russia, International Planning Studies, 17:4, 333-352

Lefebvre, Henri. 2009 [1940]. Dialectical Materialism. Minneapolis: University of Minnesota Press.

Marais, M. 2002. Visions of Excess: Closure, Irony, and the Thought of Community in Ivan Vladislavić's The Restless Supermarket. English in Africa, 29, 2: 101-117.

Myers, Garth. 2014. Unexpected Comparisons. Singapore Journal of Tropical Geography, 35, 1: 104-118. 
Parnell, Susan and Sophie Oldfield. (eds) 2014. Handbook for Cities of the Global South. London: Routledge.

Peck, Jamie, Nik Theodore, and Neil Brenner. (2009) 'Neoliberal urbanism: Models, moments, mutations', SAIS Review, XXIX(1): pp. 49-66.

Popescu, Monica. 2003. Translations: Lenin's Statues, Post-communism, and Post-apartheid. The Yale Journal of Criticism, 16, 2: 406-423.

Robinson, Jennifer. 2010. Living in Dystopia: Past, present and future in contemporary urban development, in Gyan Prakash (ed) Noir Urbanisms, Princeton University Press, pgs 218-240.

Robinson, Jennifer. 2011. Cities in a World of Cities: The Comparative Gesture. International Journal of Urban and Regional Research 35 (1): $1-23$.

Robinson, Jennifer. 2013. The Urban Now: Theorising Cities Beyond the New. European Journal of Cultural Studies, 16: 659-677.

Robinson, Jennifer. 2016. Thinking Cities through Elsewhere: Comparative Tactics for a more Global Urban Studies. Progress in Human Geography 40 (1): 3-29.

Robinson, Jennifer and Susan Parnell. 2011. Traveling Theory: Embracing Post-Neoliberalism through Southern Cities. In The New Blackwell Companion to the City, edited by G. Bridge and S. Watson. Chichester: Wiley-Blackwell, pgs 521-531.

Rogers, Douglas. 2010. Postsocialisms Unbound: Connections, Critiques, Comparisons. Slavic Review, 69, 1: 1-15.

Roy, Ananya. 2009. The 21st-Century Metropolis: New Geographies of Theory. Regional Studies 43 (6): 819-830.

Simone, Abdoumaliq. 2011. The surfacing of urban life. City, 15, 3-4: 355364.

Smith, Adrian. 2007. 'Articulating neo-liberalism: diverse economies and urban restructuring in post-socialism', in Sheppard, E., Leitner, H. and Peck, J. (eds.) Contesting Neoliberalism: The Urban Frontier, Guilford, pp. 204-222

Spivak, Gyatri. 1988. Can the Subaltern Speak?" In Cary Nelson and Lawrence Grossberg, eds.,Marxism and the Interpretation of Culture, pp. 271-313. Urbana: University of Illinois Press, 1988.

Stanek, Lukasz. 2012. Introduction: the 'Second World's' architecture and planning in the 'Third World', The Journal of Architecture, 17:3, 299-307 
Stanilov, Kiril and Ludek Sýkora. 2014. Confronting Suburbanization: Urban Decentralization in Postsocialist Central and Eastern Europe. Oxford: Wiley-Blackwell.

Tuvikene, Tauri. 2016. Strategies for comparative urbanism: post-socialism as a de-territorialized concept. International Journal of Urban and Regional Research 40 (1): 132-146.

Vladislavić, Ivan. 1989. Missing Persons. Cape Town: David Philip.

Vladislavič, Ivan. 1996. Propaganda by Monuments and other stories. Cape Town and Johannesburg: David Philip.

Vladislavić, Ivan. 2000. Interview with Ivan Vladislavić (by Christopher Warnes). Modern Fiction Studies, 46, 1: 273-

Vladislavić, Ivan. 2001. The Restless Supermarket. Cape Town: David Philip.

Vladislavić, Ivan. 2006. Portrait with Keys: Johannesburg Unlocked. New York: WW Norton and Company.

Warnes, Christopher. 2000. The Making and Unmaking of History in Ivan Vladislavić's Propaganda by Monuments and Other Stories. Modern Fiction Studies, 46, 1: 67-89.

Yiftachel, Oren. 2006: Re-Engaging Planning Theory? Towards 'SouthEastern' Perspectives, in Planning Theory, 5, 211-222 